\title{
AN OVERVIEW OF MALLET FINGER (BASEBALL FINGER) SURGICAL TREATMENT THE LAST 10 YEARS.
}

Luiz Valério Costa Vasconcelos (Universidade de Fortaleza (Unifor), Fortaleza, CE, Brasil), Igor Quezado Araújo De Andrade (Universidade de Fortaleza (Unifor), Fortaleza, CE, Brasil), Fernando Parahyba Diogo

De Siqueira (Universidade de Fortaleza (Unifor), Fortaleza, CE, Brasil), Camille Mapurunga Tavares (Centro Universitário Christus (Unichristus), Fortaleza, CE, Brasil), Leonardo Barros Bastos (Universidade de Fortaleza (Unifor), Fortaleza, CE, Brasil), John Kennedy Torres De Alencar (Universidade de Fortaleza

(Unifor), Fortaleza, CE, Brasil), Marina Isidório Cruz Macêdo (Universidade de Fortaleza (Unifor),

Fortaleza, CE, Brasil), Ana Clara De Fátima Marques Pimentel (Universidade de Fortaleza (Unifor), Fortaleza, CE, Brasil)

\section{BACKGROUND}

INTRODUCTION: Mallet finger is an injury of the extensor digitorum tendon of the fingers at the distal interphalangeal joint and it results from hyperflexion of the extensor digitorum tendon. The mallet injury disables the patient to straighten the tip of the finger or thumb, which may inflict many restrictions in someone's personal life. This abnormality may be surgically repaired, what demands longitudinal followup by the medical team in order to improve the life quality of the patient.

\section{MATERIALS AND METHODS}

METHODOLOGY: Epidemiological, descriptive and retrospective study, whose data was collected from Hospital Information System (SIH/SUS) from January/2009 to January/2019 by analyzing the variables: age group, geographic region, deaths, hospitalization and mortality rate.

\section{RESULTS}

RESULTS: According to DATASUS, from January/2009 to January/2019, 8,997 Hospital Admission Orders to surgical treatment of mallet finger (baseball finger) were approved in Brazil. The number of admissions was greater in the Southeast and smaller in the North of the country. There were 5,014 hospitalizations in the Southeast region, 2,127 hospitalizations in the South, 751 hospitalizations in the Northeast region and 301 hospitalizations in the North of the country.

\section{CONCLUSION}

CONCLUSION: From the data collected, it was possible to conclude that the Southeast was the region with the greatest number of hospitalizations $(5,014)$, and the North was the region with the smallest number of hospitalizations (301). The South presented 2,127 hospitalizations and the Northeast presented 751 hospitalizations. From these numbers, it is possible to infer the need of more attention from the health care system in Brazil to the Southeast region. 